\title{
Po prostu siedzieć. Wymiary siedzenia z perspektywy buddyzmu zen
}

\section{Abstract \\ Just Sitting. Dimensions of Sitting from a Zen Buddhist Perspective}

The article deals with the subject of the sitting figure, which seems to be an important element of both practice and reflection in Buddhism. The real inspiration to write this article was the introduction of quarantine in many countries, including Poland, and this fact certainly changed the lifestyle of many people, contributing significantly to the immobilization of many of them. Looking at this situation through the prism of Buddhism, especially Zen Buddhism, to which most of the information contained in this text refers, would be best considered only as a contribution to reflection on the cultural dimensions of the „sitting figure, . This figure, at least from the Buddhist perspective, seems to be an important element conditioning the view of reality.

Keywords: sitting, Zen Buddhism, Buddha, Bodhidharma, Dōgen, Eastern philosophy, Eastern culture, Buddhism in the West

Należy rozłożyć cienką matę i na poduszce usiąść w pełnej pozycji lotosu - położyć prawą nogę na lewym udzie, a lewą nogę na prawym. Ubranie i pas powinny być rozluźnione, ale nie w nieładzie. Prawą dłoń należy położyć na lewej nodze, tak aby można było na niej położyć lewą dłoń, łącząc kciuki obu dłoni. Następnie należy przemieścić obie dłonie tak, aby kciuki znalazły się na wysokości pępka, wyprostować się, nie przechylając się ani do przodu, ani do tyłu, ani na boki. Uszy powinny być na linii barków, nos na linii pępka. Język powinien być przyciśnięty do podniebienia, usta i zęby zaciśnięte. Nie wolno zamykać oczu, powinny być lekko zmrużone ${ }^{1}$.

${ }^{1}$ Opis praktyki zazen według zaleceń Dōgena (Kozyra 2004: 121-122). 
Teza stawiana w tym artykule jest prosta. Można ją sprowadzić do lakonicznego wręcz stwierdzenia, iż sztuka pozornie bezczynnego siedzenia wymaga od większości z nas sporego wysiłku. Niemniej w niektórych przypadkach jej praktykowanie zdaje się warunkować zdolność dostrzegania niezauważanych dotychczas wymiarów rzeczywistości. Tak przynajmniej można powiedzieć, jak sądzę, w odniesieniu do buddyzmu zen, lecz także ogólnie do buddyzmu pojmowanego nie tylko jako religia czy system filozoficzny, ale właśnie rodzaj praktyki, której sens szczególnie oddaje figura siedzenia.

Problem wynikający z postawionej tezy zamierzam zilustrować, opierając się na tekstach autorów o nie tylko naukowej proweniencji, które pochodzą z różnych źródeł, na ogół pisanych, i które szczególnie wiążą się z refleksją z zakresu buddyzmu zen. Lecz tego nurtu buddyzmu, kierując się już tylko potrzebą określenia jego kulturowych tudzież historycznych uwarunkowań, pod wieloma względami raczej nie należy zbytnio separować od ogólnego pojęcia buddyzmu przedstawianego - korzystając z formy określenia proponowanej przez Ireneusza Kanię - także jako rodzaj „Nauki” (Kania 1999: 7). Jej podstawowe założenia przypisuje się postaci Siddharthy Gautamy, często też określanego jako Budda lub Budda Saâkyamuni² (przyjmuje się, że żył w latach 566-486 p.n.e.) (Mejor 1980: 43-44). Nazwy te w dalszej części artykułu zamierzam stosować zamiennie, jakkolwiek każdą z nich traktuję przede wszystkim w kategoriach znaku wskazującego na pewien symbol wiedzy zawartej w pojęciu „buddyzm”.

Jednym z ważniejszych impulsów do napisania tego artykułu stał się przymus lockdownu, który został wprowadzony nie tylko w Polsce (marzec 2020 r.) w związku z rozprzestrzenianiem się informacji na temat koronawirusa oraz skutków, jakie on powoduje. W tym kontekście zaczęły pojawiać się różne teksty kultury komentujące ten stan rzeczy. Treść jednego $\mathrm{z}$ takich tekstów, jeśli za taki można uznać to, co jest przedstawiane $\mathrm{w}$ formie tzw. memów czy wpisów umieszczanych na portalach społecznościowych, sprowadza się mniej więcej do takiej formy:

Możesz uratować świat, siedząc na tyłku, nie robiąc nic. Tylko tego nie zepsuj.

Mniej więcej taki wpis na Facebooku zwrócił moją uwagę na problem, który zamierzam przybliżyć. Gwoli rzetelności muszę jednak dodać, iż starając się wyszukać memy o podobnej do przedstawionej treści, o wiele częściej natrafiałem jednak na ten rodzaj przekazu, w myśl którego owym zbawiennym dla świata zaleceniem na czas lockdownu byłoby leżenie przed telewizorem. Nie chcę rozstrzygać, które z zaleceń może przynieść więcej korzyści zarówno światu, jak też jednostce decydującej się na jedną z zalecanych praktyk. Mogę jedynie stwierdzić, iż wariant wskazujący na figurę siedzenia o tyle przemówił do mojej wyobraźni, o ile za jego

${ }^{2}$ Ponieważ w tym tekście odnoszę się głównie do pojęć i uogólnień z zakresu buddyzmu zen, zdecydowałem się wykorzystać transliterację, jaką zastosowała Agnieszka Kozyra w pracy Filozofia zen (Kozyra 2004). 
sprawą, na zasadzie skojarzenia, przypomniałem sobie niektóre ze scen i treści, jakie pojawiły się w japońskim filmie Zen z 2009 r., który wyreżyserował Banmei Takahashi ${ }^{3}$ Rzez jasna dotyczyły one kwestii siedzenia. Na dobrą sprawę właśnie w odniesieniu do wybranego przeze mnie fragmentu, który pochodzi z tego filmu, zamierzam zbudować narrację, jakkolwiek nie jest to jedyna inspiracja.

Mówiąc bowiem o impulsach, które pchnęły mnie w stronę sporządzenia tego opracowania, rzetelnie będzie, jeśli wspomnę również o rozmowie telefonicznej z Grzegorzem L. Piotrowskim, malarzem zamieszkałym w okolicach Kalwarii Zebrzydowskiej, mniej więcej w trzecim tygodniu odgórnie wprowadzonego przymusu pozostania w domu. Piotrowski dużo mówił na temat tego, że nie tylko on w efekcie zaleconego unieruchomienia zauważa w domowym otoczeniu to, czego wcześniej nie dostrzegał, mimo iż od lat mieszka w tym samym miejscu. Wspomniał o ptakach w ogrodzie, które wcześniej nie zwróciły jego uwagi w aż tak dużym stopniu. Dodał też, że wcale nie jest prostym zadaniem siedzenie w jednym miejscu, co szczególnie wymowne w przypadku osoby, którą postrzegam jako kogoś, kto bardzo dużo energii wkłada w utrzymywanie stosunkowo dużej liczby relacji społecznych także poza domem. Przywołany tu artysta przybliżył też refleksje niektórych swoich znajomych na temat dostrzeganych przez nich walorów przebywania w jednym miejscu. Wielu z nich zauważyło w tym kontekście, jak wspaniałe mają dzieci bądź w jak pięknym miejscu przyszło im żyć i jak wiele można zrobić, by zadbać jeszcze bardziej o ten najbliższy świat, w tym także o siebie.

W przywołanym filmie Zen, opowiadającym o losach japońskiego mnicha, mistrza i nauczyciela Dōgena (żył w latach 1200-1253), któremu przypisuje się przyniesienie z Chin buddyzmu chan i zaszczepienie go w Japonii - gdzie zaczęto go określać jako buddyzm zen - w odmianie sōtō, znalazła się scena, która zdaje się być szczególnie wymowna w kontekście takich pojęć jak „kryzys” czy „strach”, ale także „siedzenie”. Scena ta rozgrywa się w założonym przez Dōgena w Eihei klasztorze w początkowym okresie jego funkcjonowania. Przedstawia problem sygnalizowanego przez szefa kuchni braku pożywienia, co wyraża dialog prowadzony między głównym bohaterem a jednym z mnichów:

- Nie mamy już ryżu ani kaszy.

- Jeśli nie ma wystarczająco ryżu, przygotujcie owsiankę.

- Jeśli nie ma wystarczająco owsianki?

- Przygotujcie kleik.

- Jeśli nie ma wystarczająco kleiku?

- W takim wypadku będziemy pić gotowaną wodę i siedzieć w zazen. Odciąć się zupełnie od normalnego życia [kontynuuje Dōgen - G. D.], porzucić wszystko, do czego byliście przywiązani. Porzucić myślenie o tym, co dobre i złe, i o samym myśleniu, łącznie z myślą o oświeceniu. Porzucić wszystkie intencje, zamiary i myśli. To zwie się nie-myśleniem. Nie siedzimy w zazen, aby uzyskać oświecenie. Zwykłe siedzenie w medytacji jest samo w sobie oświeceniem4 ${ }^{4}$.

3 Link do filmu: https://www.cda.pl/video/309798356 (dostęp: 14.07.2020).

4 Początek tej sceny następuje mniej więcej w 1:13 min filmu. 
Podkreślając ten fragment, ze szczególnym wskazaniem na sposób zareagowania na niewątpliwie bardzo egzystencjalny problem, bynajmniej nie zamierzam wskazywać na uniwersalizm objawiający się zalecaniem określonej formy unieruchomienia mniejszej bądź większej społeczności w obliczu dostrzeżonego zagrożenia. Bardziej zależy mi na podkreśleniu znaczenia i roli tego, co zostało w nim sprowadzone do pojęcia siedzenia, szczególnie w obrębie kulturowych zachowań z zakresu buddyzmu zen. Z pewnością warto też będzie odnieść się do innych pojęć, jakie znalazły się w przywołanym wyimku, jakkolwiek i te zostały już w nim samym wstępnie doprecyzowane.

Przybliżenie tego, czym jest siedzenie w zazen, można rozpocząć od odpowiedniego fragmentu z książki Sztuka prostego życia, napisanej przez współcześnie żyjącego mnicha buddyjskiego Shunmyo Masuno. Jego zdaniem warto zastanowić się nad tym, żeby raczej „zmienić siebie,, niż świat, który nie zawsze spełnia nasze oczekiwania. Proponując całkiem sporą liczbę "praktycznych wskazówek” mogących pomóc w „osiąganiu szczęścia i spokoju”, Masuno tak pisze na temat zazen:

Zazen jest najważniejszym elementem treningu zen. Nie można mówić o zen bez zazen. Zaczynamy od zazen i na nim kończymy: na tym polega nasza praktyka (Masuno 2019: 51).

Dalej autor wyjaśnia, czym jest praktyka zen. Stara się przy tym wskazać na niejako „zdroworozsądkowe” jej konsekwencje. Przy tej okazji, w postaci zalecenia, zwraca subtelnie uwagę na „korzyści” płynące z praktykowania zazen, o ile, rzecz jasna, „czystość umysłu” można uznać za wartość dodaną. Oto dalsza część wypowiedzi Masuno:

Słowo „zen” pochodzi od sanskryckiego słowa dhyana oznaczającego „cichą kontemplację”.

Akt myślenia wywodzi się od koncepcji siedzenia w ciszy, ludzie nie są bowiem zdolni do kontemplacji w ruchu. Mamy tylko jeden umysł, a kiedy skupiamy się na ruchach, trudno nam się oddać głębokim przemyśleniom.

Nawet jeśli próbujesz rozmyślać nad czymś podczas spaceru, twoje myśli zawsze będą dotyczyć takich praktycznych kwestii jak praca lub gotowanie obiadu. Nie jesteś w stanie wówczas medytować nad absolutną prawdą czy sensem życia.

Przed przystąpieniem do zazen przyjmujemy prawidłową postawę, następnie skupiamy się na oddechu, a na końcu uspokajamy umysł. Dopiero po zajęciu się tymi trzema obszarami możemy przejść do właściwej praktyki.

Wypróbuj zazen na siedząco: oczyść umysł, uwolnij myśli i pozwól im odpłynąć (Masuno 2019: 51).

W świetle tej uwagi, szczególnie stwierdzenia, iż zazen jest „najważniejszym elementem treningu zen, od którego zaczyna i kończy się ta praktyka, nie powinna dziwić postawa przeora nowo powstałego klasztoru buddystów zen, Dōgena, który miast martwić się o pożywienie, w pierwszej kolejności zaleca właśnie siedzenie.

Biorąc pod uwagę, iż na temat buddyzmu zen czy tylko tego, co wiąże się z samym pojęciem „zen”, nie brak literatury, zarówno tej naukowej, jak i, ogól- 
nie rzecz ujmując, pozanaukowej, z pewnością napotkamy całkiem sporą liczbę obrazów tego, czym w istocie jest i z czym wiąże się ta refleksja, nauka, wiedza, doktryna, religia, filozofia czy także praktyka. $Z$ tego też powodu nie zamierzam czynić wykładu na ten temat poza szczególnym wskazaniem na praktyczny wymiar buddyzmu czy szczególnie buddyzmu zen. Niemniej, zwłaszcza w obliczu poczucia zagrożenia zdrowia i w kontekście takich pojęć, jak „wirus”, „zakażenie”, „epidemia” czy w końcu „pandemia”, nie mówiąc o ekonomicznych, politycznych, społecznych, a w efekcie także kulturowych skutkach unieruchomienia społecznego, dosyć wymowną w tym względzie zdaje się być wypowiedź profesora filozofii buddyjskiej Daisetza Teitaro Suzukiego na temat tego, czym jest zen:

Zen tym przede wszystkim różni się od innych szkół religijnych, filozoficznych czy też mistycznych, że nie opuszczając ani na chwilę sfery życia codziennego, będąc tak praktycznym i konkretnym, ma jednak w sobie coś, co wynosi go ponad plugastwo i niepokoje tego świata (Suzuki 1987: 6).

Świadomie rezygnując z próby opisania owego „czegoś”, chcę jednak podkreślić, iż także Suzuki - jak i wielu innych autorów piszących na ten temat - wskazuje na praktyczny wymiar zen.

W literaturze z zakresu buddyzmu, pisanej zarówno przez teoretyków, jak i praktyków, spotkamy na ogół bardzo zbliżone poglądy na temat samej postaci Buddy i tego, co wiąże się z przypisanymi właśnie jej precedensami, które do niedawna tylko w krajach azjatyckich, a dziś już także na wszystkich zamieszkałych przez człowieka kontynentach znalazły swoich kontynuatorów. Niekoniecznie należałoby pojmować to zjawisko wyłącznie w kategoriach zachowań religijnych, aczkolwiek ten wymiar zdaje się być szczególnie czytelny. Jak pisze Marek Mejor:

Buddyzm powstał w czasach historycznych, w VI w. p.n.e. na północy Indii, w nizinie nadgangesowej.

Dziś nie ulega już wątpliwości historyczność postaci jego założyciela, zwanego Buddą (sanskr. buddha znaczy „przebudzony”, „oświecony”). Stare teksty kanoniczne przedstawiają go jako wzniosłego mędrca, doskonale oświeconego najwyższym poznaniem, który nauczał ludzi odkrytej prawdy o cierpieniu i wyzwoleniu z cierpienia (Mejor 1980: 7).

W kontekście tego artykułu warto przytoczyć fragment dotyczący „rozpoznania", jakiego miał dokonać Budda Saākyamuni, a szczególnie przykład interpretacji Kani. W pierwszej kolejności należałoby zapoznać się z tekstem źródłowym:

Ponieważ w całym wszechświecie rozpoznał on świat takim, jakim jest, wyzwolił się od niego w pełni - on nie mający sobie we wszystkich światach równego. On, bohater wszystko przemagający, wolny jest od wszelkich więzów; osiągnął nirwanę, pokój najwyższy nie obciążony żadnym lękiem. To jest Budda, wolny od skalań, wyzbyty cierpień, ten, który unicestwił zwątpienie. Osiągnął on również zniszczenie wszelkiego karmana oraz uwolnił się od „pozostałości” (Kania 1999: 35). 
Tak natomiast zinterpretował ten fragment tłumacz, który w swojej wypowiedzi wyjaśnia nie tylko znaczenie pojęcia „budda” (buddha), ale również wskazuje na to, jak można pojmować to, co w buddyzmie określa się jako „przebudzenie”, a zatem:

Zwykły człowiek żyje jak we śnie - w otoczeniu form, rzeczy, rojeń, projekcji własnego ducha, zhipostazowanych znaków językowych i pojęć, które bierze za rzeczywiste (tj. Substancjalne i trwale) byty. Ten, kto zdaje sobie sprawę z ich prawdziwej istoty (tj. nesubstancjalności), kto widzi świat w jego prawdzie, staje się "przebudzonym”, buddą; słowo to (buddha) jest przecież imiesłowem czasu przeszłego od pierwiastka budh, „budzić” (Kania 1999: 35).

Nie jest to wszystko, co na temat przetłumaczonego z języka palijskiego tekstu napisał Kania, który nie omieszkał przy tej okazji przywołać innych ważnych z perspektywy buddyzmu pojęć, m.in. takich jak dharma (nauka), „pustka” czy „Wolność”. Niemniej, jak sądzę, wybrany przeze mnie wyimek pozwala zauważyć zasadę, w myśl której znak wskazujący na konkretny przedmiot jest tylko znakiem, a nie tym przedmiotem, na który wskazuje, podobnie jak odbicie księżyca w tafli jeziora nie jest księżycem, tylko właśnie jego odbiciem. W świetle tego można nawet zauważyć, iż pojęcie Buddy zdaje się być w pewnym sensie, paradoksalnie, stosunkowo arbitralnym znakiem tego, że nic nie jest arbitralne, ponieważ wszystko podlega zmianie, $w$ tym także wszelkie relacje typu „znaczone” i „znaczące”. Tego typu poglądy głosił chociażby Nagardżuna (około 200 r. n.e.), indyjski filozof z kręgów buddyjskich, autor doktryny pustki (śūnyatā), w myśl której wszystko jest relatywne i wzajemnie uwarunkowane, przez co nic nie może istnieć samoistnie, autonomicznie. Zdaniem Alana W. Wattsa tego typu rozpoznanie zostało też wyrażone w anonimowym dziele funkcjonującym pod nazwą Sutry serca (Watts 1997: 89), w którym znajduje się m.in. taki oto zapis:

[...] forma nie jest różna od pustki,

pustka nie jest różna od formy.

Forma to właśnie pustka,

pustka to właśnie forma ${ }^{5}$.

Analizowanie tej formuły nie jest celem tego artykułu, jakkolwiek należałoby w tym miejscu zaznaczyć, iż przytoczone tu zdanie, opisujące dialektykę pojęć pustki i formy, na co zwraca uwagę Watts, nie tyle odnosi się do opisu rzeczywistości, ile do naszych wyobrażeń na jej temat. Co równie ważne, z perspektywy buddyzmu o wiele bliższe prawdy jest stwierdzenie, iż rzeczywistość i tak jest taka, jaka jest (Watts 1997: 93). Zdaniem przywołanego autora sprowadzenie tego problemu do pojęcia "takości” (tathata) ma w przypadku buddyzmu konkretny cel:

${ }^{5}$ Sutra serca wielkiej pradźni-paramity (Mahā-prajnā-pāramitā-hrdaya-sūtra), przeł. M.St. Zięba (Kudelska 2002: 240). 
Zadaniem takich bezsensownych określeń jest zwrócenie naszej uwagi na to, że logika i znaczenie - z zakodowaną w sobie dwoistością - są własnością myśli i języka, a nie otaczającego nas świata. W niewerbalnym, konkretnym świecie nie ma żadnych klas i żadnych symboli, które znaczą lub oznaczają cokolwiek innego niż siebie same. Stąd w świecie nie ma też dwoistości. Dualizm pojawia się bowiem przy klasyfikacji, kiedy rozdzielamy nasze doświadczenia do przegródek w naszych umysłach - przegródka, aby być przegródką, musi mieć wnętrze odgrodzone od części zewnętrznej (Watts 1997: 100).

Dalsze brnięcie w wyjaśnianie zawiłości pojęć buddyjskich, które wynikają z doświadczenia egzemplifikowanego przez Buddę, grozi odejściem od podjętego tematu, jakim jest, mówiąc ogólnie, siedzenie. Niemniej w przypadku tej kategorii, przynajmniej w kontekście buddyzmu, również i ta figura, jeśli chce się wskazać na w miarę rozpoznawalny sens, który jest jej nadawany, zdaje się być ściśle wpisana w dialektykę wyznaczaną przez pojęcia - posługując się terminologią z zakresu buddyzmu zen - zazen i „oświecenie”. Należy uściślić, iż pojęcie oświecenia zasadniczo zdaje się być późniejszym odpowiednikiem pojęcia "nirwana”, określającego m.in. stan, jaki osiągnął Siddhartha Gautama, stając się „Przebudzonym” (zob. Kania 1999: 27, 62). Warto zwrócić uwagę, iż wszelkie próby opisania tego, do czego odsyła pojęcie oświecenia (jap. satori), w zasadzie i tak skazane są na niepowodzenie, gdyż problem dotyczy postrzegania - przez osobę, która osiągnęła ten stan - rzeczywistości nieujętej w ramy stwarzane przez pojęcia i struktury języka. Z drugiej strony wielu autorów, w tym tych wywodzących się z kultur Wschodu, wśród których znajdują się także ci, z prac których korzystam, pisząc ten artykul, próby takie podejmuje. Tak na ten temat pisze m.in. cytowany już wcześniej Suzuki:

Satori to nieoczekiwany rozbłysk w świadomości nowej prawdy, o której się nawet nie śniło. [...] Satori nadchodzi, kiedy człowiek najmniej się go spodziewa, gdy czuje, że dał już z siebie wszystko. W sensie religijnym są to nowe narodziny, w sensie intelektualnym - zdobycie nowego punktu widzenia. Świat wygląda teraz, jakby przystrojony był w nową szatę, która zdaje się okrywać całą brzydotę dualizmu, przez buddyzm zwanego ułudą (Suzuki 2017: 117).

„Brzydota dualizmu” zdaje się wyzierać także w przypadku prób opisania relacji, jakie zachodzą między pojęciami „oświecenie” i zazen, oraz także tymi pojęciami, które w przypadku buddyzmu zen w istotny sposób się z nimi łączą. Przykłady na to można znaleźć chociażby w opracowaniu Agnieszki Kozyry na temat „filozofii zen”, której wspomniana autorka przygląda się z perspektywy koncepcji „absolutnie sprzecznej samotożsamości”. W każdym razie, bardziej $\mathrm{w}$ celu zilustrowania tej kwestii, niźli z potrzeby poszerzania ram tematycznych artykułu, warto przybliżyć kilka uwag wspomnianej autorki na temat „jedności praktyki [zazen - G.D.] i oświecenia", będącej przedmiotem opisu przywołanego już wcześniej Dōgena. Aby „rozważyć sens” jego teorii, jak pisze Kozyra, „należy rozważyć ten problem w kontekście najważniejszych wątków filozofii [Dōgena], która jest w pewnym sensie konsekwentnym rozwinięciem teorii uniwersalnej »natury buddy« Dōgen szukał bowiem odpowiedzi na następujące pytanie: Jaki 
jest sens praktyki, skoro człowiek zawsze ma "naturę buddy«?” (Kozyra 2004: 120). Założeniem koncepcji „uniwersalnej »natury buddy «” jest to, że każdy człowiek „naturę” taką posiada, choć zdaniem Dōgena nie wszyscy ludzie zdają się objawiać tę buddyjską „prawdę” w swoich zachowaniach, zwłaszcza ci, którzy nie są wolni od cierpienia, pasji i żądz. Przy tej okazji zwraca on uwagę na istotną rolę, jak określa to autorka Filozofii zen, „medytacji w pozycji siedzącej”, którą praktykował Budda Śākyamuni oraz jego następcy (Kozyra 2004: 20). Jak dalej relacjonuje przywołana tu autorka:

Według Dōgena prawdziwa medytacja jest „odrzuceniem jaźni i ciała” (jap. shinjin datsuraku), co umożliwia odkrycie prawdziwej jaźni, która jest „pustką”. Tylko ten, kto odrzuca podmiot i przedmiot poznania, dociera do „pustki” uświadamiając sobie fundamentalną jedność wszystkich fenomenów (Kozyra 2004: 20).

„Medytacja w pozycji siedzącej”, jak zauważa dalej Kozyra, jest przez Dōgena traktowana jako „praktyka dla samej praktyki”, i jak dalej pisze autorka, „[...] w pewnym sensie staje się wyrazem "oświecenia ", a nie sposobem na jego osiągnięcie” (Kozyra 2004: 121). Owo wtrącenie, „w pewnym sensie”, zdaje się być bardzo istotne, bo gdyby go nie było, można by pomyśleć, iż Dōgen nie w pełni kontynuuje postawę historycznego Buddy. W tym wypadku stawianie akcentu na praktykę siedzenia $\mathrm{w}$ zazen należy przede wszystkim odczytać jako rodzaj zalecenia, by tylko na akcie siedzenia koncentrować uwagę, nie zaś na świadomym dążeniu do uzyskania „natury Buddy drogą medytacji” (Merton 2003: 41).

Powyższy przykład pokazuje, jak sądzę, iż „dualizm” uwarunkowany przez reguły „języka” jako prawdopodobnie jednej z ważniejszych kategorii definiującej gatunek ludzki, zmuszający w tym przypadku do rozdzielnego traktowania przywołanych pojęć, zazen i „oświecenie”, rzeczywiście zdaje się sprzyjać powstawaniu barier utrudniających dostęp nie tylko do tego, co może stanowić o sensie buddyzmu, ale także wpływać na brak spójnej wizji wśród tych, którzy piszą na jego temat. Według Mejora (1980: 46) to właśnie akt siedzenia oraz towarzysząca temu intencja poprzedzają przemianę Siddharthy („Ten, który dopiął celu”), dzięki czemu staje się on Buddą, kimś, kto potrafi „rozpoznać świat takim, jakim jest”:

$\mathrm{Z}$ mocnym postanowieniem zdobycia oświecenia zasiadł pod wielkim drzewem figowym ( $\mathrm{w}$ tradycji zwie się je „drzewem bodhi”, czyli „oświecenia”). Po 7 tygodniach wzniosłej kontemplacji, [...] odkrył tajemnicę życia i śmierci i drogę do wyzwolenia. Osiągnął najwyższe i doskonałe oświecenie - bodhi, które uczyniło go Buddą - Oświeconym, Przebudzonym (531 r. p.n.e.). Po krótkim wahaniu postanowił ogłosić światu odkrytą prawdę (Mejor 1980: 47).

Bardzo możliwe, iż z perspektywy buddyjskiej wizji świata nie jest aż tak bardzo istotne to, czy sprowadzony do konwencjonalnej formy akt siedzenia jest „warunkiem”, czy „wyrazem” „przebudzenia”, „oświecenia”, „dotarcia do pustki”, „osiągnięcia stanu buddy” etc. Natomiast w świetle rozległej literatury dotyczącej buddyzmu niewątpliwie figura siedzenia, jako środek mogący warunkować „przemianę”, dzięki której jednostka przeżywa „nowe narodziny” tudzież zyskuje 
„nowy punkt widzenia”, jest istotnym elementem transmisji tradycji kulturowej sygnowanej przez pojęcie „Budda”. W każdym razie, jak należałoby przypuszczać, element ten niejednokrotnie zdaje się być ważniejszy od przekazu dokonanego za pomocą spisanych czy wypowiadanych słów, o czym informuje następujący fragment traktujący na temat jednego z wymiarów praktyki zen:

A zatem zen z całą mocą i uporem domaga się wewnętrznego przeżycia. Nie przywiązuje on istotnej wagi ani do świętych sutr, ani do ich egzegezy przez mędrców i uczonych. Autorytetom i obiektywnym odkryciom przeciwstawia zdecydowanie osobiste przeżycie, a jego wyznawcy jako najlepszy środek na osiągnięcie duchowego oświecenia proponują uprawianie dhjany, zwanej po japońsku zazen (Suzuki 2017: s. 40-41).

Istotnym symbolem transmisji buddyzmu jest na wpół legendarna postać Bodhidharmy, uważanego za 28 patriarchę buddyzmu oraz za pierwszego patriarchę powstałego w Chinach, około VI w. n.e., buddyzmu chan, kontynuacją którego jest buddyzm zen. Na marginesie warto zauważyć, iż to właśnie przy okazji wspominania tej postaci $\mathrm{w}$ literaturze $\mathrm{z}$ zakresu buddyzmu zen autorzy zwykle przywołują takie pojęcia, jak dhyāna czy zazen (jap.), których bynajmniej nie należy odnosić wyłącznie do siedzenia, lecz raczej do medytacji czy kontemplacji. Niemniej to właśnie Bodhidharmie przypisuje się, co zdaje się być wyraźną mityzacją, tak wielkie zaangażowanie w praktykę medytacyjną, która miała polegać właśnie na siedzeniu ze skrzyżowanymi nogami, iż - rzekomo - w efekcie patriarsze odpadły nogi (zob. Kozyra 2004: 113).

O symbolicznym wymiarze Bodhidharmy świadczyć też może samo pojęcie bodhidharma, które tworzą dwa elementy - bodhi oraz dharma, co można czytać jako „przebudzenie dharmy”, czyli przebudzenie nauk głoszonych przez Buddę. W tym przypadku pojęcie przebudzenia ma o tyle szczególną pojemność, że nie tylko podkreśla jednostkowe doświadczenie, lecz także transmisję buddyzmu poza obszar jego powstania oraz jego wejście w dialog z elementami innych kultur, choćby z chińskim taoizmem (por. Merton 2003: 20). Na dobrą sprawę postać Bodhidharmy wskazuje też na to, że buddyzm chan, a później zen, który przynajmniej od jej czasów pojmowany bywa również jako „doświadczenie”, „droga” czy „życie” (por. Merton 2003: 8), jest w istocie wypadkową tradycji, które w modelowy sposób należałoby wiązać z kulturą Indii, Chin czy Japonii. W praktyce oznacza to również, że wraz z buddyzmem, rozprzestrzeniającym się niekoniecznie tylko na zasadzie „bezpośredniego przekazu”, „bez użycia pisma i słownych formułek", co, podobnie jak Budda, zdawał się również podkreślać Bodhidharma (zob. Merton 2003: 20), migrować zaczęły związane z nim pojęcia, czego ilustracją może być chociażby ten fragment:

Wu, pierwszy cesarz dynastii Liang (panował w latach 502-549 n.e.), zadał Bodhidharmie (Daruma w Japonii; Tamo w Chinach), Pierwszemu Patriarsze chińskiej sekty zen, pytanie dotyczące najwyższej i najświętszej zasady buddyzmu. Mędrzec miał na to odpowiedzieć: „Ogromna pustka, a w niej nic świętego" (Suzuki 2017: 61). 
Opis i analiza kolejno przywoływanych pojęć z zakresu buddyzmu nie jest celem tego artykułu. Niemniej przy okazji przybliżania postaci Bodhidharmy uchodzącego za osobę, która dokonała bezpośredniego przekazu nauk Buddy oraz zapisała się na kartach historii jako niewątpliwy symbol siedzenia w pozycji zazen - warto podkreślić, iż akt długotrwałego siedzenia w skupieniu w tym konkretnym przypadku można potraktować jako ilustrację nie tyle funkcji, ile narzędzia sprzyjającego „oczyszczaniu umysłu”. $Z$ tej perspektywy także pojęcie pustki mogłoby oznaczać taki stan tegoż umysłu, którego nie mąci już żadna abstrakcyjna myśl, oraz że zdolny jest on postrzegać świat w jego „takości”. Niezależnie od różnych koncepcji na ten temat, poza wskazaniem, że pojęcie pustki nie musi wyłącznie odnosić się do spekulacji filozoficznych z zakresu relacji wyznaczanej właśnie przez pojęcie „pustka”, ale i „forma”, warto podkreślić, że już tylko $\mathrm{w}$ przypadku przybliżonych $\mathrm{w}$ tym artykule postaci, $\mathrm{tj}$. - ujmując je $\mathrm{w}$ porządku chronologicznym - Buddy, Bodhidharmy i Dōgena, figura siedzenia zdaje się być nader istotnym elementem.

Trudno jest zapewne wskazać na symbol, czyli postać pokroju Bodhidharmy czy Dōgena, która w sposób urastający do rangi symbolu podkreślałaby fakt, jakim jest transmisja buddyzmu na grunt społeczeństw zachodnich, co nastąpiło w XX wieku i co historyk Arnold Toynbee miał porównać do odkrycia energii jądrowej (zob. Kozyra 2004: 23), lecz przynajmniej w kontekście buddyzmu zen można dostrzec, już tylko na podstawie literatury, iż recepcja przybliżanego w tym artykule zjawiska, także na Zachodzie, ściśle wiąże się z pojęciem zazen. W pracy zatytułowanej Trzy filary zen jej autor - Philip Kapleau, który po odbyciu w Japonii kilkunastoletniej praktyki i studiów w zakresie buddyzmu zen uzyskał tytuł oraz prawo do dalszego przekazywania nauk, których głoszenie przypisuje się Buddzie - przybliża, wraz ze szkicami, postawy zazen. Autor wymienia na pierwszym miejscu „postawę pełnego lotosu”, dalej „postawę półlotosu”, „ćwierćlotosu”, "postawę birmańską" czy „japońską". Wszystkie one wiążą się z siedzeniem na ułożonej bezpośrednio na podłodze macie, na której umieszcza się specjalną poduszkę służącą do podkładania jej pod pośladki. Jest jednak też propozycja postawy zazen na krześle, niemniej i w tym przypadku, siłą rzeczy, wskazanie dotyczy siedzenia (Kapleau 2012: 351-354).

Jednym z polskich mistrzów zen jest Aleksander Poraj-Żakiel, który, w przeciwieństwie do Kapleau, nie ubiera się już w szaty japońskich mnichów zen, gdyż jest mistrzem zen tzw. świeckiej linii. Tytuł ten dziedziczy po zmarłym niedawno Willisie Jägerze, benedyktynie i mistrzu zen. Był on założycielem ponadwyznaniowej linii zen pod nazwą „Pusta Chmura”, której największa siedziba w Europie znajduje się w niemieckim Holzkirchen. Poraj-Żakiel, podobnie zresztą jak Dōgen, tłumaczy, iż zrozumienie tego, czym jest zen, zależy od zrozumienia tego, czym jest zazen. Natomiast, jak pisze dalej, „[...] aby zrozumieć zazen musimy je praktykować, czyli przeżywać. Innej drogi nie ma" (Poraj-Żakiel 2018: 41). Przy tej okazji autor zauważa jednak, że pojęcie zazen stało się wręcz synonimem po- 
jęcia „medytacja siedząca”, chociaż nie są tożsame, gdyż, jak twierdzi, „postawa zazen sama w sobie nie ma żadnych ograniczeń ani nawet takich nie zakłada" (Poraj-Żakiel 2018: 41). Według Poraja-Żakiela jedynym warunkiem poznania, czym jest zen, jest jego doświadczanie (Poraj-Żakiel 2018: 41).

Wskazując na zachodnich mistrzów zen, a przy okazji dostrzegając dosyć dużą spójność treści, które wyrażają w swych tekstach, z tym, co można chociażby na temat zen czy zazen przeczytać w literaturze przedmiotu traktującej głównie o azjatyckich przedstawicielach tego nurtu buddyzmu, warto podkreślić, iż są to postaci, które nie podchodzą do opisywanego przez nich zagadnienia w sposób wyłącznie teoretyczny, co w konsekwencji nie tylko pozwala zauważyć, iż trudno jest mówić o zen bez praktykowania zazen. Czytelne bowiem, jak sądzę, jest również i to, że praktyka zen nie musi wiązać się wyłącznie z religijnym wymiarem ludzkich zachowań, co szczególnie zdaje się zauważalne właśnie w kontekście zachodniej recepcji buddyzmu zen. Prawidłowość tę dałoby się prawdopodobnie również wykazać w odniesieniu do tego, co wiąże się z „doświadczaniem” buddy$\mathrm{zmu}$ w warunkach kultury Wschodu. Nie jest to jednak temat tego artykułu.

Całkiem interesujące wnioski $\mathrm{w}$ związku $\mathrm{z}$ odniesieniem się do pojęcia zazen z perspektywy figury siedzenia czy wręcz „medytacji w pozycji siedzącej” można znaleźć w pracy kolejnego zachodniego praktyka zen, Claude’a Durixa, autora pracy Sto kluczy zen. Ten chirurg okulista w 1956 r. trafił do Japonii jako zawodnik judo i zaczął praktykować zen, stając się uczniem Rosiego Sengoku. Wśród omawianych przez autora Stu kluczy... istotnych jego zdaniem pojęć z zakresu buddyzmu zen znalazły się też fragmenty poświęcone zazen w tej odmianie, która wiąże się właśnie z figurą siedzenia. Zdaniem Durixa „Zazen to wielki klucz, który otwiera szafę z pozostałymi kluczami” (Durix 2006: 25). Pisze:

„Za” oznacza siedzenie. Zazen to inaczej medytacja zen na siedząco. Dla Dogena jest to nawet sama esencja zen: „Zen, to tylko zazen”. Zen to tylko siedzenie. Nic więcej. W tym zawiera się wszystko. Wydaje się to proste - ale czy takie jest?

Postawa, oddech, stan umysłu - oto trzy podstawowe elementy zazen (Durix 2006: 25).

W dalszej kolejności powołuje się na to, iż w znajdującym się w dolinie Indusu kompleksie ruin Mohendżodaro, należącym do cywilizacji wyprzedzającej czasy Buddy o prawie dwa tysiące lat, „[...] znaleziono rzeźbione pieczęcie przedstawiające postacie siedzące w zazen" (Durix 2006: 25).

Durix pisze dalej:

Zazen, siedzenie w wielkiej koncentracji, wynik duchowych doświadczeń wielu tysiącleci jest postawą prostą i bardzo naturalną (Durix 2006: 25).

Opis „,iedzenia w wielkiej koncentracji”, będącego w istocie, jak chciałby tego autor Stu kluczy... siedzeniem w pozycji zazen, zasadniczo nie różni się od tego, co obrazują już wcześniej przywołani autorzy, tj. Dōgen, Kapleau czy Poraj-Żakiel. Odpowiednia postawa, jak uważa Durix, jest „sednem zazen”. To jednak nie 
wszystko, na co zwraca uwagę autor, który ma wykształcenie medyczne. Jego zdaniem „sednem” siedzącej postawy zazen jest piąty kręg lędźwiowy:

O tej, nie należącej do największych pośród dwustu części naszego szkieletu, można powiedzieć, że przewodzi „ministerstwu jakości naszego życia”: jest zwornikiem łuku w architekturze ludzkiego ciała i jest być może jednym z ważniejszych kluczy do zrozumienia zen. Bez niego nie byłaby możliwa właściwa postawa (Durix 2006: 106).

Piąty kręg lędźwiowy, jak można dalej przeczytać, odpowiada za [...] „naturalne wygięcie kręgosłupa", zaś jego uszkodzenie bądź deformacja sprawiają, że cała postawa ciała ludzkiego ulega wypaczeniu (Durix 2006: 108).

Rozważania Durixa na temat postawy zazen, a szczególnie „zwornika łuku w architekturze ludzkiego ciała", oraz informacje na temat znalezisk z Mohendżodaro, które zdają się pośrednio wskazywać, iż sposób siedzenia sprowadzany najczęściej do pojęć dhyana bądź zazen, teoretycznie można by wiązać z liczącą około czterech i pół tysiąca lat tradycją, potencjalnie pozwalają przyjąć, iż sens siedzenia według pochodzącego $\mathrm{z}$ doliny Indusu wzoru nie zamyka się tylko w medytacji, lecz odnosi się też do kulturowo ukonstytuowanej praktyki służącej dbaniu o zdrowie i sprawne funkcjonowanie ciała. W świetle tego, co Peter L. Berger i Thomas Luckmann piszą na temat mechanizmów społecznego konstruowania rzeczywistości kulturowej (zob. Berger, Luckmann 1983: 213), można wręcz zaryzykować stwierdzenie, iż dokonane jeszcze w starożytnych Indiach okraszenie swoistej wiedzy na temat pragmatycznych walorów siedzenia w określonej postawie pojęciami i narracjami z zakresu dyskursu religijnego zdaje się być o wiele skuteczniejszą metodą zachęcającą do praktykowania dhyany czy wiele wieków później zazen niż użycie rzeczowych i racjonalnych argumentów. Nie należy jednak, moim zdaniem, sprowadzać tego, co w buddyzmie wiąże się z pojęciem wiedzy, wyłącznie do figury siedzenia, podobnie jak nie należy utożsamiać samego buddyzmu tylko z siedzeniem. Jeden ze współczesnych nauczycieli zen, Jakusho Kwong, nie zaleca sprowadzania pojęcia zazen wyłącznie do siedzącej medytacji:

Ludzie lubią siedzieć w zazen i głównie na tym się skupiają, lecz nie wiedzą, że w życiu codziennym wszystko jest zazen (Kwong 2016: 173).

Powyższa wypowiedź zdaje się wskazywać, że pojęcie zazen należałoby też odnosić do rodzaju koncentracji czy stanu szczególnej uwagi, jaki może osiągnąć człowiek nie tylko poprzez praktykowanie odpowiedniego sposobu siedzenia.

Jednak to właśnie pojęcie siedzenia w odniesieniu do buddyzmu, szczególnie buddyzmu zen, jest punktem uwagi w tym artykule. $\mathrm{Z}$ tego też względu warto jeszcze wrócić do tego, co na temat fizjologii w kontekście „medytacji w pozycji siedzącej" pisze Durix, zdaniem którego temu zagadnieniu należałoby poświęcić obszerną publikację.(Durix 2006: 303). Autor powołuje się na badania medyczne, jakie przeprowadzono wśród osób będących w trakcie praktykowania zazen. We- 
dług niego „korzystne” zmiany, jakie udało się dostrzec, dotyczyły m.in. spadku częstotliwości oddechu, zmniejszenia aktywności krwiobiegu, obniżenia się poziomu kwasu mlekowego we krwi czy spowolnienia metabolizmu. Zazen miałoby też sprzyjać odzyskiwaniu przez kręgosłup jego „naturalnej krzywizny” oraz znacząco wpływać na poprawę jego kondycji, dając w ten sposób odpocząć nadwerężanym „przez złe nawyki” dyskom międzykręgowym. Badania miały też wykazać wpływ "medytacji siedzącej” na równowagę między systemami nerwowym, mózgowo-rdzeniowym, neurowegetatywnym i sensorycznym. Dodatkowo, w przypadku kobiet, praktykowanie zazen miałoby korzystnie wpływać na okres ciąży i porodu (Durix 2006: 303-304).

Interesujące jest też to, co Durix pisze na temat wyników badań prowadzonych przy użyciu encefalogramu wśród osób praktykujących zazen. Opis wyników tych badań warto poprzedzić fragmentem dotyczącym zakresu fal elektromagnetycznych, jakie można zmierzyć w ludzkim mózgu:

[...] normalny stan czuwania z otwartymi oczami odpowiada wykresowi aktywności z rytmami o słabej amplitudzie, który nazywany jest rytmem beta $(15$ do $30 \mathrm{~Hz})$ i rytmem alfa (8 do $13 \mathrm{~Hz})$. Stanowi snu, z zamkniętymi oczami, odpowiada rytm delta (1 do $3 \mathrm{~Hz}$ ). Rytm alfa dominuje $\mathrm{w}$ tylnych regionach mózgu i zanika w momencie otwarcia oczu lub wysiłku umysłowego. Rytm teta jest powolnym rytmem od 4 do 7,5 Hz i występuje rzadziej (Durix 2006: 304).

Jak się okazuje, stopień zaawansowania w praktykowaniu zazen w pozycji siedzącej przekłada się na większą czytelność zmian widocznych na wykresach encefalogramu, natomiast, co warto podkreślić, fale teta występują wyłącznie u osób o bardzo długim doświadczeniu w praktyce zazen (Durix 2006: 304-305).

Osoby potrafiące osiągnąć stan umysłu, który można zdefiniować za pomocą fal teta, miałyby wykazywać się większą czujnością i zdolnością dostrzegania bodźców zewnętrznych, zarówno jednorazowych, jak i powtarzających się. Innymi słowy, wieloletni praktycy zazen nie przyzwyczajają się do stałych bodźców, np. takich jak tykanie zegara, tylko wciąż są uważni. Jak pisze Durix:

[...] na poziomie aktywności mózgu wykazywanym przez encefalograf, zazen jest stanem spokojnej czujności, charakteryzującym się ciągłą uwagą, nieustanną wrażliwością na zewnętrzne bodźce. Jak widać, daleko zen do kwietyzmu, z którym jest często utożsamiany (Durix 2006: 305).

Warto w kontekście przedstawionych w tym artykule informacji - zwłaszcza dotyczących praktycznego wymiaru stanu zazen - przywołać raz jeszcze słowa Allana Wattsa, który zdaje się należeć do elitarnego grona autorów wykazujących podobny dystans względem zarówno kultury Zachodu, jak i kultury Wschodu:

Zachodnie pojmowanie praktyk buddyjskich jest bardzo często zniekształcone przez ugruntowaną opinię o „tajemniczości Wschodu” i przez sensacyjne wymysły tak szeroko rozpowszechniane w pismach teozoficznych w ciągu dwudziestolecia przełomu wieków [XIX i XX - przyp. G. D.]. Wymysły te nie opierały się na bezpośrednich badaniach buddyzmu, lecz na dosłownym rozumieniu fragmentów sutr, w którym buddom i bodhisattwom przypisuje się 
niezliczone cudowne i ponadludzkie zdolności. Nie wolno więc mylić mistrzów zen z teozoficznymi „mahatmami” - olśniewającymi „Mistrzami Mądrości”, którzy żyją w górskich fortecach Tybetu i oddają się praktykom okultystycznym. Mistrzowie zen są jak najbardziej ludźmi. Chorują i umierają, wiedzą, co to radość i smutek, miewają kiepski humor i inne małe „ułomności” charakteru, jakie ma każdy człowiek, i nie są im obce miłość i najzupełniej ludzki związek z płcią odmienną. Pełnia zen to sztuka bycia w pełni i po prostu człowiekiem (Watts 1997: 198).

Zbliżając się do puenty, chciałbym wyrazić pewne przypuszczenie, w myśl którego możliwym jest to, iż w wyniku odgórnego unieruchomienia związanego z epidemią koronawirusa wiele osób mogło dostrzec związek, jaki zachodzi, mówiąc modelowo, między „siedzeniem” w jednym miejscu a wzrostem uwagi względem tego, co wydarza się w najbliższym otoczeniu. Jednak pisząc ten artykuł - zrodzony z pomysłu, jaki pojawił się właśnie w kontekście lockdownu i między innymi powstałych w związku z nim pomysłów, że siedzenie może okazać się metodą ratowania ludzkości - zależało mi przede wszystkim na tym, ażeby zwrócić uwagę nie tyle na symboliczny wymiar figury siedzenia w buddyzmie, ile na praktyczny walor buddyzmu wiążący się m.in. z zaleceniem siedzenia w odpowiedniej pozycji. $Z$ tego też powodu starałem się bazować na tych tekstach, które wiążą się z buddyzmem zen, gdyż ich autorami bardzo często są praktycy, którzy niejednokrotnie zdają się prezentować postawę wolną od nadmiernego mityzowania rzeczywistości i opisujących ją tekstów, czego nie można powiedzieć o wielu badaczach, także tych wywodzących się z kręgów zachodniej kultury, którzy traktują buddyzm wyłącznie jako religię czy system filozoficzny, jakkolwiek i ten rodzaj optyki jest uzasadniony.

Wracając raz jeszcze do hasła „Możesz uratować świat, siedząc na tyłku, nie robiąc nic. Tylko tego nie zepsuj” oraz kierując się przesłaniem, jakie zdaje się płynąć z pism pochodzącego z Wietnamu mnicha buddyjskiego Thich Nhat Hanha, chciałbym zaproponować problem do rozważenia. Wiąże się on z pytaniem o wartość, szczególnie w kontekście lockdownu, siedzenia w domu: czy rzeczywiście warto robić to dla świata, czy może raczej dla siebie? Z perspektywy buddyzmu podpowiedź w ujęciu Hanha brzmi następująco:

gdy ktoś naprawdę dba o siebie, dba zarazem o wszystkich (Hahn 2006: 22).

Kierując się tą refleksją, powinienem już tylko odwołać się do słów, które rzekomo wypowiedział Budda. Ich sens warto odczytać według klucza, który zaproponował tłumacz starobuddyjskich tekstów na język polski, Ireneusz Kania. Najpierw Budda:

Postanowiłem, o mnisi, znaleźć istotę przyjemności cielesnej. I znalazłem, o mnisi, istotę przyjemności cielesnej. W tej mierze, w jakiej przyjemność cielesną da się poznać, i ujrzałem ją wyraźnie.

Postanowiłem, o mnisi, znaleźć niebezpieczeństwo ciała. I znalazłem, o mnisi, niebezpieczeństwo ciała. W tej mierze, w jakiej niebezpieczeństwo ciała da się poznać, ujrzałem je wyraźnie. 
Postanowiłem, o mnisi, znaleźć sposób uniknięcia ciała. I znalazłem, o mnisi, sposób uniknięcia ciała. W tej mierze, w jakiej sposób uniknięcia ciała da się poznać, ujrzałem go wyraźnie. (Itd., tak samo odnośnie emocji, postrzeżeń, energii, świadomości.) (Kania 1999: 161).

Natomiast interpretację słów autorstwa Kani z powodzeniem można potraktować jako istotny element puenty niniejszego opracowania:

Budda podkreślał niejednokrotnie, że źródła jego nauczania są na wskroś empiryczne - nie wyspekulowane ani objawione. Wszystko, o czym mówi, sam poznał i przeżył w doświadczeniu bogatego i długiego życia (Kania 1999: 161).

Do tego też, jak sądzę, zachęca wielu buddystów, by - mówiąc metaforycznie - znaleźć „Buddę w sobie”, co należałoby odczytać jako wskazówkę, by sposób rozpoznania własnej osoby uzależniać od własnego doświadczenia (zob. Suzuki BRW $\left.{ }^{6}: 43\right)$, niekoniecznie zaś od teoretycznych uogólnień na temat człowieka. Natomiast to, co zostało przywołane w tym tekście za pośrednictwem pojęć $d h y$ ana czy zazen, wiążąc się $\mathrm{w}$ dużej mierze $\mathrm{z}$ figurą siedzenia, być może jest jednym z ważniejszych zaleceń warunkujących wspomniany rodzaj rozpoznania. Szczególnie w kontekście lockdownu można zauważyć, że jest to sytuacja wymuszająca statyczny rytm życia, lecz niekoniecznie wiążąca się z umiejętnością każdej zmuszonej do tego osoby, by w razie takiej potrzeby - mówiąc oględnie - potrafić usiąść i w ten sposób nie tylko doświadczać świata, będąc w wiecznym ruchu, lecz uczyć się w nim być i oglądać go, także i siebie, z nieco bardziej statycznej perspektywy

Kończąc, należałoby podkreślić, iż przywoływana najczęściej w tym tekście figura siedzenia ukonstytuowała się prawdopodobnie w okolicach Doliny Indusu, lecz związana $\mathrm{z}$ nią praktyka wykroczyła poza ten obszar, definiując przy tym istotny wymiar zachowań kulturowych wielu społeczeństw azjatyckich. Od XX wieku ta konkretna figura staje się też elementem praktyki wielu przedstawicieli współczesnego świata, którzy na skutek globalizacji nie przynależą już wyłącznie do kontynentu azjatyckiego. Warto to zauważać, chociażby w kontekście śledzenia zmian kulturowych, które mogą zależeć zarówno od tego, co ma związek z procesami adaptacyjnymi, jak i od dyfuzji różnego rodzaju elementów kultury w sensie largo. Nie jest to jednak problem tego artykułu, w którym, na dobrą sprawę, chodziło wyłącznie o wskazanie - przy użyciu konkretnych przykładów z zakresu buddyzmu zen - na pewną zależność, w myśl której celowe siedzenie w odpowiedni sposób oraz wiążący się z tym rodzaj koncentracji mogą, mówiąc bardzo ogólnie, sprzyjać osobie uciekającej się do tego typu praktyki w dostrzeganiu przez nią tych wymiarów rzeczywistości, które wcześniej umykały jej uwadze, włączając w to refleksję dotyczącą tego, iż różne formy unieruchomienia bynaj-

${ }^{6}$ Publikacja ta, jako Zen Mind, Beginner's Mind, ukazała się po raz pierwszy w 1970 r. w Weatherhill, Nowym Jorku i Tokio. Niestety w polskim wydaniu nie znalazła się informacja na temat roku wydania, nie podano także nazwiska tłumacza. Korzystałem z opracowania wydanego w Gdyni o numerze ISBN 83-00-03426-9. 
mniej nie skutkują przysłowiowym „końcem świata”, czym dla wielu ludzi mógł być przymus pozostania $\mathrm{w}$ domu, zwłaszcza dla tych, których dotychczasowa aktywność wiązała się z codziennym ruchem i przemieszczaniem z miejsca do miejsca Nie sądzę przy tym, aby lockdown miał w jakiś wyraźny sposób stać się czynnikiem warunkującym kolejne wymiary buddyzmu w wersji zachodniej. Zasadność dostrzegania takiej zależności trudno byłoby obronić. Co najwyżej można jedynie skorzystać z zasobu doświadczeń z zakresu buddyzmu, zwłaszcza tych potencjalnie wiążących się $\mathrm{z}$ formą unieruchomienia ciała $\mathrm{w}$ pozycji siedzącej, by w ten sposób spróbować dostrzec nieznane dotąd relacje, które warunkuje szeroko $\mathrm{w}$ tym wypadku pojęta figura siedzenia. W każdym razie buddyzm niewątpliwie jest tym lustrem kulturowej odmienności, w tafli którego, szczególnie w kontekście siedzenia, niekiedy warto się przejrzeć, by w ten sposób poszerzyć chociażby refleksję w zakresie doświadczania lockdownu, co dla wielu osób sprowadziło się do pozostania na dłuższy czas, „siedzenia”, w jednym miejscu.

\section{Bibliografia}

Berger P.L., Luckmann T.

1983 Społeczne tworzenie rzeczywistości, przeł. J. Niźnik, Warszawa.

Durix C.

2006 Sto kluczy zen, przeł. P.J. Ilukowicz, Poznań.

Hanh T.N.

2006 Nauki o miłości, przeł. S. Musielak, Poznań.

Kania I.

1999 Muttāvali. Księga wypisów starobuddyjskich, Kraków.

Kapleau P.

2012 Trzy filary zen. Nauka, praktyka, oświecenie, przeł. J. Dobrowolski, Łódź.

Kozyra A.

2004 Filozofia zen, Warszawa.

Kudelska M. (red.)

2002 Filozofia Wschodu. Wybór tekstów, Kraków.

Kwong J.

2016 Bez początku, bez końca. Intymne serce zen, przeł. M. Kłobuchowski, Kielce.

Masuno S.

2019 Sztuka prostego życia. 100 wskazówek, jak osiagnać szczęście i spokój, przeł. K. Bochenek, Warszawa.

Mejor M.

1980 Buddyzm, Warszawa.

Merton T.

2003 Mistycy i mistrzowie zen, przeł. T. Biedroń, Poznań. 
Poraj-Żakiel A.

2018 Wprowadzenie do zen. Historia - praktyka - współczesność, Wrocław. 2002 Sutra serca wielkiej pradżni-paramity (Mahā-prajnā-pāramitā-hrdaya-sūtra), przeł. M. St. Zięba, w: Kudelska (red.) Filozofia Wschodu. Wybór tekstów, Kraków, s. $240-242$.

Suzuki D.T.

1987 Wstęp, w: Zen w sztuce łucznictwa, przeł. M. Kłobukowski, Warszawa, s. 5-8. 2017 Wprowadzenie do buddyzmu Zen, przeł. M. i A. Grabowscy, Warszawa.

Suzuki S.

BRW Umysł zen, umysł początkującego, Gdynia.

Watts A.W.

1997 Droga zen, przeł. S. Musielak, Poznań. 